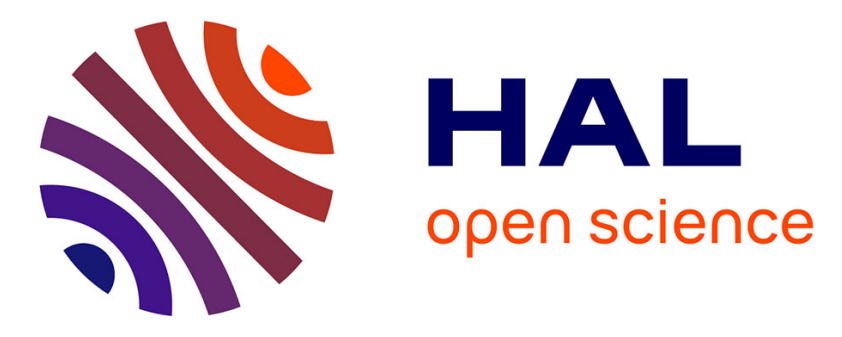

\title{
Mammea-type coumarins from Mammea usambarensis Verdc.
}

Joseph Magadula, Pax Masimba, Rose Tarimo, Zaituni Msengwa, Zakariah H Mbwambo, Matthias Heydenreich, Dimitri Bréard, Pascal Richomme

\section{- To cite this version:}

Joseph Magadula, Pax Masimba, Rose Tarimo, Zaituni Msengwa, Zakariah H Mbwambo, et al.. Mammea-type coumarins from Mammea usambarensis Verdc.. Biochemical Systematics and Ecology, 2014, 56, pp.65-67. 10.1016/j.bse.2014.05.004 . hal-03287473

\section{HAL Id: hal-03287473 \\ https://univ-angers.hal.science/hal-03287473}

Submitted on 15 Jul 2021

HAL is a multi-disciplinary open access archive for the deposit and dissemination of scientific research documents, whether they are published or not. The documents may come from teaching and research institutions in France or abroad, or from public or private research centers.
L'archive ouverte pluridisciplinaire HAL, est destinée au dépôt et à la diffusion de documents scientifiques de niveau recherche, publiés ou non, émanant des établissements d'enseignement et de recherche français ou étrangers, des laboratoires publics ou privés. 


\title{
Mammea-type coumarins from Mammea usambarensis Verdc.
}

\author{
Joseph J. Magadula ${ }^{a, *}$, Pax J. Masimba a , Rose B. Tarimo ${ }^{a}$, Zaituni Msengwa ${ }^{a}$, \\ Zakariah H. Mbwambo ${ }^{\text {a, }}$ Matthias Heydenreich ${ }^{\mathrm{b}}$, Dimitri Breard ${ }^{\mathrm{c}}$, \\ Pascal Richomme ${ }^{\mathrm{c}}$ \\ ${ }^{a}$ Institute of Traditional Medicine, Muhimbili University of Health and Allied Sciences, P.O. Box 65001, Dar es Salaam, Tanzania \\ ${ }^{\mathrm{b}}$ Institut fur Chemie, Universitat Potsdam, Postfach 601553, D-14415 Potsdam, Germany \\ c SONAS-UFR Sciences Pharmaceutiques, 16 Bd Daviers, F-49100 Angers, France
}

\section{A R T I C L E I N F O}

\section{Article history:}

Received 7 February 2014

Accepted 3 May 2014

Available online 24 May 2014

\section{Keywords:}

Mammea usambarensis

Isolations

Mammea-type coumarins

Chemotaxonomy

\begin{abstract}
A B S T R A C T
Phytochemical investigations of Mammea usambarensis resulted into the isolation a $\delta$-tocotrienol (1) and five known mammea-type coumarins (2-6). Their structures were determined by NMR, IR, and LC-MS spectroscopic methods and by comparison of their spectral and physical data with those reported previously in the literature. The presence of these compounds is consistent with the compound classes reported from other members of the genus Mammea. Compound $\mathbf{6}$ is isolated from the Mammea genus for the first time. This is the new source of mammea-type coumarin compounds while the chemotaxonomic significance of this investigation is summarized.
\end{abstract}

(c) 2014 Elsevier Ltd. All rights reserved.

\section{Subject and source}

Mammea usambarensis Verdc. is a tropical plant in the Clusiaceae family. It is endemic to the Eastern arc mountains along the North-eastern, Tanzania where it is known for its edible fruits with no any report on its use in traditional medicine. This study investigates the stem barks and fruits of $M$. usambarensis collected from Shagayu forest reserve in Lushoto district, Tanga region, Tanzania in October 2011. Plant material was authenticated by Mr Haji O. Suleiman of the Botany department, University of Dar es Salaam, Tanzania. Voucher specimen (HOS 3429) has been deposited in the herbarium at the Institute of Traditional Medicine, Tanzania.

\section{Previous work}

The genus Mammea belongs to the family Clusiaceae and is made up of about seventy (70) species growing in the tropical regions all over the global, two (2) of which (Mammea africana and M. usambarensis) are native to the mainland Africa (Janick and Paull, 2008). Many of the species of the genus Mammea are used in traditional medicine for the treatment of various diseases such fever, internal heat, stomach pains, scabies and microbial infections (Chapius et al., 1988). Phytochemical studies of members of genus Mammea have reported a number of mammea-type coumarin compounds. It is reported from the literature that, thirty-nine (39) mammea-type coumarins have been previously isolated and identified from various parts of Mammea americana (Crombie and Games, 1967a,b; Crombie et al., 1970, 1972; Carpenter et al., 1971; Finnegan et al., 1972; Games, 1972; Yasunaka et al., 2005; Reyes-Chilpa et al., 2004; Yang et al., 2006; Du et al., 2010, 2001). Other Mammea species

\footnotetext{
* Corresponding author. Tel.: +255 754568702 .

E-mail addresses: jmagadula@gmail.com, magadulajanguj@yahoo.com (J.J. Magadula).
} 
that produced mammea-type coumarins include M. africana (Dongmo et al., 2007; Canning et al., 2013), Mammea siamensis (Laphookhieo et al., 2006; Ngo et al., 2010; Mahidol et al., 2002; Prachyawarakorn et al., 2006a,b), Mammea longifolia (Deng and Nicholson, 2005) and Mammea harmandii (Reutrakul et al., 2003).

In this paper, we report the isolation and characterization of a $\delta$-tocotrienol (1) and five known mammea-type coumarins (2-6) from M. usambarensis, which represents a new source of this type of compounds. Furthermore, this is the first report of the chemical constituents of $M$. usambarensis

\section{Present study}

Air dried and powdered stem bark of M. usambarensis ( $520 \mathrm{~g}$ ) was extracted with $80 \%$ aqueous ethanol at $28{ }^{\circ} \mathrm{C}$ for $24 \mathrm{~h}$ and filtered. The filtrate was evaporated under reduced pressure to afford $53.2 \mathrm{~g}$ of crude extract. $17 \mathrm{~g}$ of the crude extract was subjected to vacuum liquid chromatography (VLC) under silica gel eluting with Petroleum ether, PE (100\%), Dichloromethane, DCM (100\%), and methanol, $\mathrm{MeOH}(100 \%)$ as mobile phases. The solvents in the VLC fractions were evaporated on a rotary evaporator to afford $26 \mathrm{mg}$ (PE), $7.6 \mathrm{~g}$ (DCM) and $8.1 \mathrm{~g}(\mathrm{MeOH})$. TLC analysis of the VLC fractions indicated similarity between PE and DCM extracts, hence the two fractions were combined and chromatographed under open column over silica gel 230400 Mesh eluting, initially with 100\% PE, adding increasing amounts of DCM to 100\% DCM to give 60 fractions of 20 ml each. After TLC analysis, the following combinations were made; Fractions 1-13 showed only long chain fatty acids as analyzed by TLC, so were not followed up. Fractions 14-40 were subjected to Column Chromatography (CC) over silica gel eluting with DCM/PE, 3:2 v/v to afford compounds $1(7.2 \mathrm{mg})$ and $\mathbf{2}(132 \mathrm{mg})$ and after repeated crystallization in methanol. The combined fractions 41-60 eluted with DCM/PE (7:3 v/v) gave compounds 3 (12.6 mg) and 4 (15.1 mg).

Shade dried and grounded fruits of $M$. usambarensis (12.8 g) were soaked in DCM:MeOH (1:1) for 48 h and later the solvent was removed using rotary evaporator to afford $7.2 \mathrm{~g}$ of crude extract. About $6.0 \mathrm{~g}$ of the crude extract were subjected to CC over silica gel and eluted with DCM:PE, 1:1 v/v to afford 21 fractions. Because of the small amount and existence of complex fatty acids as viewed on the TLC, fraction 1-10 was not subjected for further purification process. Yellow crystals were observed to precipitate in combined fraction 11-21; these crystals were filtered and washed with $100 \% \mathrm{MeOH}$ to afford compound $\mathbf{5}(123 \mathrm{mg}$ ) and $\mathbf{6}$ (13.8 $\mathrm{mg})$.

The structures of isolated compounds were elucidated by analysis of MS and NMR spectroscopic data as well as by comparison of spectral data with those published in the literature. Six compounds (Fig. 1) were identified to be $\delta$-tocotrienol (1) (Laphookhieo et al., 2006; Ohnmacht et al., 2008), mammea B/BB (2) (Crombie and Games, 1967a,b; Yang et al., 2006; Dongmo et al., 2007), mammea E/BB (3) (Laphookhieo et al., 2006; Yang et al., 2006; Du et al., 2001), mammea B/BD (4) (Yang et al., 2006), mammea B/AB (5) (Crombie et al., 1970, 1972a,b) and mammea B/AB cyclo D (6) (Cruz et al., 2001). All compounds were reported for the first time as secondary metabolites of $M$. usambarensis and compound $\mathbf{6}$ is also reported for the first time in the genus Mammea.

\section{Chemotaxonomic significance}

This study represents the first phytochemical work on Mammea usambarensis and also represents the first report of isolation of mammea B/AB cyclo D (6) from the genus Mammea. Furthermore, this study reports for the first time the isolation<smiles>CCCc1cc(=O)oc2c(C(=O)C(C)CC)c(O)c(CC=C(C)C)c(O)c12</smiles>

Fig. 1. Structures of compounds isolated from stem bark and fruits of Mammea usambarensis. 
and identification of a $\delta$-tocotrienol (1) and five mammea-type coumarins (2-6) from stem barks and fruits of $M$. usambarensis. Compound $\mathbf{6}$ has been previously isolated from the stem barks of Kielmeyera lathrophyton of the family Clusiaceae (Cruz et al., 2001). Moreover, the occurrence of compounds 6 in the two genera is in agreement with the conclusion that taxonomically the two genera are closely related.

The presence of high amounts of mammea-type coumarins confirms the general similarity in the Clusiaceae family as these compounds have been previously reported from other species of the genus Mammea and other genera in the Clusiaceae family e.g. Kielmeyera (Cruz et al., 1998, 2001, Nogueira et al., 2009), Mesua (Verotta et al., 2004), Calophyllum (Itoigawa et al., 2001; Reyes-Chilpa et al., 2004) and Marila (Lopez-Perez et al., 2005).

These findings support existing data of chemotaxonomic researches on the family Clusiaceae since mammea-type coumarinis were obtained from a number of Mammea species (Laphookhieo et al., 2006). The phytochemical studies done in isolation of secondary metabolites from Mammea species indicated the dominance of mammea-type coumarins. This group of compounds may serve as easily detectable and valuable chemotaxonomic markers facilitating the identification of different Mammea species.

According to the above results, the existence of mammea-type coumarins may further provide evidence to support the morphological classification of Mammea species and suggest further molecular systematics' research.

In summary, this report extended our knowledge about the diversity of mammea-type compounds in the genus Mammea and other related genera and sets the foundation for further investigations.

\section{Acknowledgment}

The authors wish to thank Mr. Haji O. Suleiman of the Botany department, University of Dar es Salaam for collection of the plant materials used in this study. This study was partly funded by seed money from the Ministry of Health and Social Welfare, Tanzania and from Sida-MUHAS Research Capacity Strengthening Grant under Directorate of Research and Publications, Muhimbili University of Health and Allied Sciences, Tanzania.

\section{References}

Canning, C., Sun, S., Ji, X., Gupta, S., Zhou, K., 2013. J. Ethnopharmacol. 147, 259.

Carpenter, I., McGarry, E.J., Scheinmann, F., 1971. J. Chem. Soc. (C), 3783.

Chapius, J.C., Sordat, B., Hostettman, K., 1988. J. Ethnopharmacol. 23, 273.

Crombie, L., Games, D.E., 1967a. J. Chem. Soc. (C) 23, 2545.

Crombie, L., Games, D.E., 1967b. J. Chem. Soc. (C) 23, 2553.

Crombie, L., Games, D.E., Haskins, N.J., Reed, G.F., Finnegan, R.A., Merkel, K., 1970. Tetrahedron Lett. 46, 3979.

Crombie, L., Games, D.E., Haskins, N.J., Reed, G.F., 1972a. J. Chem. Soc. Perkin Trans. 1 (18), 2241.

Crombie, L., Games, D.E., Haskins, N.J., Reed, G.F., 1972b. J. Chem. Soc. Perkin Trans. 1 (18), 2248.

Cruz, F.G., Moreira, L.M., David, J.M., Guedest, M.L.S., Chavezi, J.P., 1998. Phytochemistry 47, 1363.

Cruz, F.G., da Silva-Neto, J.T., Guedest, M.L.S., 2001. J. Braz. Chem. Soc. 12, 117.

Deng, Y., Nicholson, R.A., 2005. Planta Med. 71, 364.

Dongmo, A.B., Azebaze, A.G.B., Nguelefack, T.B., Ouahouo, B.M., Sontia, B., Meyer, M., Nkengfack, A.E., Kamanyi, A., Vierling, W., 2007. J. Ethnopharmacol. 111, 329.

Du, L., Mahdi, F., Jekabsons, M.B., Nagle, D.G., Zhou, Y.-D., 2001. J. Nat. Prod. 74, 240.

Du, L., Mahdi, F., Jekabsons, M.B., Nagle, D.G., Zhou, Y.-D., 2010. J. Nat. Prod. 73, 1868.

Finnegan, R.A., Merkel, K.E., Back, N., 1972. J. Pharm. Sci. 61, 1599.

Games, D.E., 1972. Tetrahedron Lett. 31, 3187.

Itoigawa, M., Ito, C., Tan, H.T.-W., Kuchide, M., Tokuda, H., Nishino, H., Furukawa, H., 2001. Cancer Lett. $169,15$.

Janick, J., Paull, R.E., 2008. The Encyclopedia of Fruit and Nuts, first ed. CABI, London, p. 268.

Laphookhieo, S., Maneerat, W., Kiattansakul, R., 2006. Can. J. Chem. 84, 1546.

Lopez-Perez, J.L., Olmedo, D.A., del Olmo, E., Vasquez, Y., Pablo, N., Solís, P.N., Gupta, M.P., Feliciano, A.S., 2005. J. Nat. Prod. 68, 369.

Mahidol, C., Kaweetripob, W., Prawat, H., Ruchirawat, S., 2002. J. Nat. Prod. 65, 757.

Ngo, N.T., Nguyen, V.T., Vo, H.V., Vang, O., Duus, F., Ho, T.D., Pham, H.D., Nguyen, L.H., 2010. Chem. Pharm. Bull. (Tok.) $58,1487$.

Nogueira, P.C.L., Andrade, M.S., Andrade, L.M., Moraes, V.R.S., Ribeiro, A.S., Bittrich, V., Amaral, M.C.E., Ferreira, A.G., Alcantara, G.B., Leao, K.V., Alves, P.B., 2009. Biochem. Syst. Ecol. 36, 921.

Ohnmacht, S., West, R., Simionescu, R., Atkinson, J., 2008. Magn. Reson. Chem. 46, 287.

Prachyawarakorn, V., Mahidol, C., Ruchirawat, S., 2006a. Chem. Pharm. Bull. (Tok.) 54, 884.

Prachyawarakorn, V., Mahidol, C., Ruchirawat, S., 2006b. Phytochemistry 67, 924.

Reutrakul, V., Leewanich, P., Tuchinda, P., Pohmakotr, M., Jaipetch, T., Sophasan, S., Santisuk, T., 2003. Planta Med. 69, 1048.

Reyes-Chilpa, R., Estrada-Muniz, E., Ramırez-Apan, T., Amekraz, B., Aumelas, A., Jankowski, C.K., Vázquez-Torres, M., 2004. Life Sci. $75,1635$.

Verotta, L., Lovaglio, E., Vidari, G., Finzi, P.V., Neri, M.G., Raimondi, A., Parapini, S., Taramelli, D., Riva, A., Bombardelli, E., 2004. Phytochemistry 65, 2867.

Yang, H., Jiang, B., Reynertson, K.A., Basile, M.J., Kennelly, E.J., 2006. J. Agric. Food Chem. 54, 4114.

Yasunaka, K., Abe, F., Nagayama, A., Okabe, H., Lozada-Perez, L., Lopez-Villafranco, E., Muniz, E.E., Aguilar, A., Reyes-Chilpa, R., 2005. J. Ethnopharmacol. 97, 293. 